\title{
A STUDY ON RESPIRATORY PROBLEMS AND PULMONARY FUNCTION INDEXES AMONG CEMENT INDUSTRY WORKERS IN MASHHAD, IRAN
}

\author{
ANALIZA PROBLEMÓW ZE STRONY UKŁADU ODDECHOWEGO ORAZ WSKAŹNIKÓW WYDOLNOŚCI PŁUC \\ WŚRÓD PRACOWNIKÓW PRZEMYSŁU CEMENTOWEGO W MASHHAD W IRANIE
}

Mashhad University of Medical Sciences, Mashhad, Iran

${ }^{1}$ Faculty of Medicine, Department of Occupational Medicine

${ }^{2}$ Faculty of Medicine, Department of Emergency Medicine

\begin{abstract}
Background: The respiratory system is the most vulnerable system in the cement industry. This study was conducted to determine the effects of occupational exposure to cement dust on the respiratory system more thoroughly. Material and Methods: In this cross sectional study an interviewer-administered questionnaire on socio-demographic characteristics and respiratory symptoms was completed and pulmonary function tests were carried out on 100 exposed and 120 non-exposed workers at the cement factory in Mashhad, Iran. The data was statistically analyzed by SPSS 16. Results: The mean of age and work duration in the exposed group was $37.5 \pm 6.3$ and $10.7 \pm 5.4$ years compared with the non-exposed group that was $36.1 \pm 7.1$ and $10.1 \pm 5.7$ years, respectively. Levels of exposure to inhalable cement dust in the exposed group were $23.13 \mathrm{mg} / \mathrm{m}^{3}$ (higher than national occupational exposure limits for such particles). Among the exposed group, respiratory symptoms as cough ( $6 \%$ vs. $0.8 \%$ of the non-exposed) and sputum ( $7 \%$ vs. $0.8 \%$ of the nonexposed) were significantly more prevalent $(\mathrm{p}<0.05)$. Forced expiratory flow $25-75 \%\left(\mathrm{FEF}_{25-75 \%}\right)$ was significantly lower in the exposed workers compared with non-exposed ones $(\mathrm{p}<0.05)$. Also forced expiratory volume in $1 \mathrm{~s} /$ forced vital capacity $(\mathrm{FEV} / \mathrm{FVC})$ and $\mathrm{FEF}_{25-75 \%}$ had a reverse correlation with the length of employment ( $\mathrm{p}=0.000$ and $\mathrm{p}=0.003$, respectively). Conclusions: The findings of this study showed that occupational exposure to cement dust could be a significant factor of respiratory system dysfunction. Strict implementation of a respiratory protection program is recommended in cement industries. Med Pr 2015;66(4):471-477
\end{abstract}

Key words: occupational exposure, respiratory symptoms, pulmonary function test, Portland cement dust, Iran, occupational diseases

\section{STRESZCZENIE}

Wstęp: Układ oddechowy jest tym najbardziej narażonym w przypadku pracy w przemyśle cementowym. Poniższe badanie miało na celu precyzyjne określenie wpływu na układ oddechowy narażenia zawodowego na pył cementowy. Materiał i metody: W ramach analizy przekrojowej 100 narażonych oraz 120 nienarażonych na pył pracowników fabryki cementu w Mashhad w Iranie wypełniło kwestionariusz na temat cech społeczno-demograficznych oraz objawów oddechowych, a także poddało się testom wydolności płuc. Otrzymane dane zostały przeanalizowane statystycznie za pomocą SPSS 16. Wyniki: Średnia wieku oraz czas zatrudnienia dla grupy badanej wyniosły odpowiednio $37,5 \pm 6,3$ roku oraz $10,7 \pm 5,4$ roku, a dla grupy porównawczej $36,1 \pm 7,1$ roku oraz $10,1 \pm 5,7$ roku. Poziom narażenia na działanie wdychanego pyłu cementowego w grupie badanej wyniósł $23,13 \mathrm{mg} / \mathrm{m}^{3}$ i przekraczał dozwoloną krajową normę narażenia zawodowego na te cząstki. W grupie badanej takie objawy oddechowe, jak kaszel (6\% vs $0,8 \%$ w grupie porównawczej) i plwocina $(7 \%$ vs $0,8 \%)$ znacznie przeważały nad innymi $(\mathrm{p}<0,05)$. Wymuszony przepływ wydechowy $25-75 \%\left(\mathrm{FEF}_{25-75 \%}\right)$ odnotowano na znacznie niższym poziomie w przypadku narażonych pracowników w porównaniu do tych nienarażonych $(\mathrm{p}<0,05)$. Także stosunek natężonej objętości wydechowej pierwszosekundowej do natężonej pojemności życiowej $\left(\mathrm{FEV}_{1} / \mathrm{FVC}\right.$ ) oraz $\mathrm{FEF}_{25-75 \%}$ wskazywały na odwrotną korelację z długością zatrudnienia (odpowiednio: $\mathrm{p}=0,000 \mathrm{i} \mathrm{p}=0,003$ ). Wnioski: Narażenie zawodowe na pył cementowy może być ważnym czynnikiem powodującym dysfunkcję układu oddechowego. Ścisłe przestrzeganie programu ochrony układu oddechowego jest zalecane w przemyśle cementowym. Med. Pr. 2015;66(4):471-477

Słowa kluczowe: narażenie zawodowe, objawy oddechowe, test wydolności płuc, pył z cementu portlandzkiego, Iran, choroby zawodowe

Corresponding author / Autorka do korespondencji: Lahya Afshari Saleh, Mashhad University of Medical Sciences, Faculty of Medicine, Azadi Square, Pardis Campus, Mashhad-Iran, e-mail: lahya.afshari@yahoo.com Received: October 7, 2014, accepted: February 10, 2014

Funding / Finansowanie: the investigation is partially supported by Mashhad University of Medical Sciences (contract No. 910129), project titled "A study on respiratory illnesses and pulmonary function indexes among workers in a cement factory in Mashhad". Project manager: Ehsan Rafeemanesh, Ph.D. 


\section{INTRODUCTION}

Cement is one of the most important building materials in the world [1]. More than 250000 people work in concrete manufacturing [2]. The volume of cement production in Iran is high (60 million tons per year). About 27000 workers are working in cement production factories in Iran [3]. Cement mill workers are exposed to dust during various manufacturing and production processes, such as quarrying and handling of raw materials, during grinding the clinker, blending, packing and shipping of the finished products [4].

Cement is a mixture of Calcium oxide $(\mathrm{CaO})$ (62-66\%), Silicon oxide $\left(\mathrm{SiO}_{2}\right)$ (19-22\%), Aluminum tri-oxi-de $\left(\mathrm{Al}_{2} \mathrm{O}_{3}\right)(4-8 \%)$, Ferric oxide $\left(\mathrm{Fe}_{2} \mathrm{O}_{3}\right)(2-5 \%)$, Magnesium oxide (MgO) (1-2\%) and also Selenium, Thallium and other impurities. The aerodynamic diameter of cement particles range from 0.05 to $5.0 \mu \mathrm{m}$. These particles are respirable in size, hence Portland cement is important as a potential cause of occupational lung disease [4].

A high prevalence of respiratory symptoms and varying degrees of airway obstruction in relation to Portland cement exposure have been reported in many studies [5-8]. Al-Neaimi et al. [5] conducted a study among the workers of the cement factory in the United Arab Emirate, as the exposed group $(\mathrm{N}=67)$ and the workers occupationally unexposed to dusts, fumes and gases $(\mathrm{N}=134)$. Socio-demographic characteristic, smoking profile and respiratory symptoms were asked as a questionnaire pulmonary function was assessed and pulmonary function impairment was calculated for the exposed and the unexposed workers. A higher percentage of the exposed workers reported recurrent and prolonged cough, phlegm, wheeze, dyspnea, bronchitis, sinusitis, shortness of breath and bronchial asthma. Ventilatory capacity (VC), forced vital capacity (FVC), forced expiratory volume in $1 \mathrm{~s}\left(\mathrm{FEV}_{1}\right), \mathrm{FEV}_{1} / \mathrm{VC}, \mathrm{FEV}_{1} / \mathrm{FVC}$ and peak expiratory flow (PEF) was significantly lower in the exposed workers compared with the unexposed workers. These differences cannot be explained by age, body mass index (BMI) or pack-years smoked.

Ventilatory function impairment, as measured by $\mathrm{FEV}_{1} / \mathrm{FVC}$, showed that $36 \%$ of the exposed workers had some ventilatory function impairment compared with $10 \%$ of those unexposed [5]. Mirzaee et al. found such results in a cross-sectional in Iran in 2001. In this study, a total of 170 exposed and 170 unexposed employees were selected. Air transmitted personal respirable dust and total dust samples were collected in a full-time ( $8 \mathrm{~h} /$ day) shift. Their findings suggest that occupational exposure to Portland cement dust may lead to higher prevalence of respiratory symptoms and the reduction of ventilatory capacity due to existence of quartz in the raw material of cement dusts. Also measuring pulmonary functions of workers exposed to dust and the unexposed group showed a significant decrease in vital capacity, forced vital capacity, $\mathrm{FEF}_{25-75 \%}$ and $\mathrm{FEV}_{1}$ [6].

In contrast, some studies have found no difference in most respiratory symptoms or spirometric indices between exposed workers and controls [1,9-11]. Meanwhile in a longitudinal study, Zeleke et al. [1] followed 100 randomly selected cement dust exposed workers and 27 unexposed workers of 2 cement factories in Ethiopia. Two hundred and sixty-two personal measurements of total dust among 105 randomly selected workers were performed in total. The workers were interviewed and examined for respiratory symptoms and signs first in 2009 and then in 2010. The cement factory workers, when compared to controls, had a higher prevalence of chronic respiratory symptoms. But no significant differences in lung function were found between production workers and controls [1].

Fell et al. [9] evaluated 119 workers from the largest cement plant in Norway and 50 workers from a nearby control plant. The participants were asked about the history of respiratory symptoms and spirometry was performed for each individual. The prevalence of symptoms and mean pulmonary function indices were similar for the exposed workers and controls. There was no dose-response-related increase in symptoms or a decrease in lung function indices. These findings did not support the hypothesis that cement dust exposure had a negative impact on lung function or increases respiratory symptoms [9].

This study was, therefore, undertaken to more thoroughly examine the effects of occupational exposure to cement dust on the respiratory system by using a matched control group of larger size than similar designed studies $[3,7,9]$ and excluding the workers with history of chronic respiratory disease based on their pre-employment and periodic examinations.

\section{MATERIAL AND METHODS}

This cross-sectional study was conducted in a cement factory in Mashhad, Iran. The factory with about 1000 workers produces more than 2 million tons of cement and 200 milion tons of lime annually. The baseline data for the present study was collected 
between January and April 2013, and comprised total dust measurement, spirometry and a questionnaire on respiratory symptoms.

Lists of all workers at factory were used to randomly select workers for interview. The inclusion criteria were current and at least 2 years of exposure to cement dust as the exposed group and workers of the same factory without current and past exposure as the the un-exposed group. Workers were excluded if they had a history of chronic lung disease. The study was conducted in accordance with Helsinki Declaration revised in 1989. No participants refused to enter the study and the Regional Committee for Medical Research Ethics of Mashhad University of Medical Sciences approved the study.

Subjects were interviewed and "The respiratory questionnaire of the national program of silicosis control" (confirmed by the health ministry of Iran) [12] was completed, which included demographic information, job history, smoking habits, respiratory signsas well as symptoms and history of tuberculosis. Physical examination was done by a general physician. The BMI was calculated as a ratio of weight in kilograms given on height in meters squared.

A digital spirometer (Spirolab III made by MIR company, Italy) was used to measure the ventilatory function of the workers, including $\mathrm{FVC}, \mathrm{FEV}_{1}$, and $\mathrm{FEV}_{1} / \mathrm{FVC}$ and $\mathrm{FEF}_{25-75 \%}$ according to the American Thoracic Society (ATS) recommendations [13]. The procedures for the pulmonary function test were explained individually to the workers and the tests were performed by a trained, skilled technician after calibration. Additionally airborne inhalable dust was collected on cellulose acetate filter with pore size of $5 \mu \mathrm{m}$ placed in a $37 \mathrm{~mm}$ cyclone connected to a Scientific Kit Corporation (SKC) sampling pump with flow rate of $31 / \mathrm{min}$.

Data was analyzed with Statistical Package for Social Sciences (SPSS) version 16. Data was described as frequency distribution for qualitative data and cross tab for quantitative data. Chi square $\left(\mathrm{Chi}^{2}\right)$ test was used for categorical variables and independent sample T-test and analysis of variance (ANOVA) for continuous variables when comparing the means in two groups. The probability value of 0.05 and less was used as the criterion for statistical significance.

\section{RESULTS}

A total of 100 workers from the cement factory and 120 workers with no occupational exposure to dusts, fumes or gases were interviewed, examined and underwent Pulmonary Function Test (PFT). All of the participants were male. Table 1 shows demographic characteristics of the exposed and unexposed groups. As shown in the table, there was no clinically or statistically significant difference between exposed and unexposed groups.

The geometric mean of the inhalable dust exposure among the exposed group was $23.13 \mathrm{mg} / \mathrm{m}^{3}$, which exceed the Threshold Limit Value (TLV) of $10 \mathrm{mg} / \mathrm{m}^{3}$ for inhalable particles [14]. All of the exposed workers use respiratory personal protective devices. There was no worker with weight and appetite loss, fever, and sweating. Dyspnea, chest pain, cough and sputum were more common among the exposed workers. Abnormal breath sounds (wheezing and crackle) were detected in only 1 person in each group. Coughing and sputum was significantly more prevalent (Table 2 ).

Table 1. The demographic parameters of the exposed to cement dust and non-exposed groups

Tabela 1. Parametry demograficzne grupy narażonej na pył cementowy oraz porównawczej

\begin{tabular}{|c|c|c|c|}
\hline $\begin{array}{l}\text { Variable } \\
\text { Zmienna }\end{array}$ & $\begin{array}{l}\text { Study group } \\
\text { Grupa badana } \\
(\mathrm{M} \pm \mathrm{SD}) \\
(\mathrm{N}=100)\end{array}$ & $\begin{array}{c}\text { Control group } \\
\text { Grupa porównawcza } \\
(\mathrm{M} \pm \mathrm{SD}) \\
(\mathrm{N}=120)\end{array}$ & $\mathrm{p}$ \\
\hline Age [years] / Wiek [w latach] & $37.5 \pm 6.3$ & $36.1 \pm 7.1$ & $\begin{array}{l}t=1.510, d f=218 \\
p=0.13\end{array}$ \\
\hline Seniority [years] / Staż pracy [w latach] & $10.7 \pm 5.4$ & $10.1 \pm 5.7$ & $\begin{array}{l}t=0.720, d f=218 \\
p=0.47\end{array}$ \\
\hline Body mass index / Wskaźnik masy ciała $\left[\mathrm{kg} / \mathrm{m}^{2}\right]$ & $25.7 \pm 3.5$ & $26.0 \pm 3.9$ & $\begin{array}{l}t=-0.662, d f=218 \\
p=0.5\end{array}$ \\
\hline Smoking [pack-year] / Palenie tytoniu [paczkolata] & $10.0 \pm 5.4$ & $10.1 \pm 9.0$ & $\begin{array}{l}t=-0.002, d f=29 \\
p=0.99\end{array}$ \\
\hline
\end{tabular}

M - mean / średnia, SD - standard deviation / odchylenie standardowe.

$\mathrm{t}$ - Student's t-distribution / rozkład t-Studenta, df - degree of freedom / stopień swobody. 
Table 2. Respiratory clinical findings in cement exposed workers in comparison with the non-exposed group

Table 2. Wyniki kliniczne pracowników narażonych na pył cementowy oraz grupy porównawczej

\begin{tabular}{lccc}
\hline \multicolumn{1}{c}{$\begin{array}{c}\text { Variable } \\
\text { Zmienna }\end{array}$} & $\begin{array}{c}\text { Study group } \\
\text { Grupa badana } \\
{[\mathrm{n}(\%)]}\end{array}$ & $\begin{array}{c}\text { Control group } \\
\text { Grupa porównawcza } \\
\text { [n (\%)] }\end{array}$ & $\begin{array}{c}\mathrm{N}=120) \\
\text { (N = 100) }\end{array}$ \\
\hline Dyspnea / Duszność & $8(8)$ & $5(4.1)$ & 0.23 \\
Sputum / Plwocina & $7(7)$ & $1(0.8)$ & $0.02^{*}$ \\
Cough / Kaszel & $6(6)$ & $1(0.8)$ & $0.04^{*}$ \\
Chest pain / Ból w klatce piersiowej & $2(2)$ & $1(0.8)$ & 0.59 \\
Wheezing and crackle / Świsty i trzaski & $1(1)$ & $1(0.8)$ & 1.00 \\
\hline
\end{tabular}

* Significantly different from its corresponding value in the non-exposed group / Istotnie różna od odpowiadającej jej wartości dla grupy porównawczej (p < 0,05).

Table 3. Predicted lung function in the exposed and non-exposed group

Tabela 3. Przewidywana wydolność płuc dla grupy badanej i porównawczej

\begin{tabular}{|c|c|c|c|}
\hline $\begin{array}{l}\text { Variable } \\
\text { Zmienna }\end{array}$ & $\begin{array}{l}\text { Study group } \\
\text { Grupa badana } \\
(\mathrm{M} \pm \mathrm{SD}) \\
(\mathrm{N}=100) \\
{[\%]}\end{array}$ & $\begin{array}{c}\text { Control group } \\
\text { Grupa porównawcza } \\
(\mathrm{M} \pm \mathrm{SD}) \\
(\mathrm{N}=120) \\
{[\%]}\end{array}$ & $\mathrm{p}$ \\
\hline $\mathrm{FEV}_{1}$ & $96.8 \pm 12.8$ & $99.5 \pm 13.4$ & $\begin{array}{l}t=-1.54, d f=218 \\
p=0.12\end{array}$ \\
\hline FVC & $97.7 \pm 11.6$ & $99.6 \pm 12.5$ & $\begin{array}{l}t=-1.13, d f=218 \\
p=0.26\end{array}$ \\
\hline FEV 1\% & $82.2 \pm 5.2$ & $83.2 \pm 5.4$ & $\begin{array}{l}t=-1.45, d f=218 \\
p=0.14\end{array}$ \\
\hline $\mathrm{FEF}_{25-75 \%}$ & $96.1 \pm 23.4$ & $102.9 \pm 24.8$ & $\begin{array}{l}\mathrm{t}=-2.06, \mathrm{df}=218 \\
\mathrm{p}=0.04^{*}\end{array}$ \\
\hline
\end{tabular}

$\mathrm{FEV}_{1}$ - forced expiratory volume in $1 \mathrm{~s} /$ natężona objętość wydechowa pierwszosekundowa, FVC - forced vital capacity / natężona pojemność życiowa, FEV $1 \%-\mathrm{FEV}_{1} / \mathrm{FVC} /$ stosunek $\mathrm{FEV}_{1}$ do natężonej pojemności życiowej, FEF - forced expiratory flow / natężony przepływ wydechowy.

Other abbreviations as in Table 1 / Inne skróty jak w tabeli 1.

* As in Table 2 / Jak w tabeli 2.

Table 4. The correlation between pulmonary function indices and age, employment duration, pack-year smoking and body mass index Tabela 4. Korelacja pomiędzy wskaźnikami wydolności płucnej a wiekiem, długością zatrudnienia, paleniem tytoniu oraz wskaźnikiem masy ciała

\begin{tabular}{|c|c|c|c|c|}
\hline $\begin{array}{l}\text { Variable } \\
\text { Zmienna }\end{array}$ & $\mathrm{FVC}$ & $\mathrm{FEV}_{1}$ & FEV $1 \%$ & $\mathrm{FEF}_{25-75 \%}$ \\
\hline \multicolumn{5}{|l|}{ Age / Wiek } \\
\hline Pearson correlation / korelacja Pearsona & 0.09 & 0.01 & -0.25 & -0.12 \\
\hline Sig (2-tailed) / istotność testu Sig (2-stronnego) & 0.15 & 0.82 & $0.00^{*}$ & 0.07 \\
\hline \multicolumn{5}{|l|}{ Seniority / Staż pracy } \\
\hline Pearson correlation / korelacja Pearsona & 0.00 & -0.10 & -0.25 & -1.97 \\
\hline Sig (2-tailed) / istotność testu Sig (2-stronnego) & 0.95 & 0.11 & $0.00^{*}$ & $0.00^{*}$ \\
\hline \multicolumn{5}{|l|}{ Smoking / Palenie tytoniu } \\
\hline Pearson correlation / korelacja Pearsona & 0.04 & -0.08 & -0.25 & -0.19 \\
\hline Sig (2-tailed) / istotność testu Sig (2-stronnego) & 0.83 & 0.66 & $0.00^{*}$ & $0.00^{*}$ \\
\hline \multicolumn{5}{|l|}{ Body mass index / Wskaźnik masy ciała } \\
\hline Pearson correlation / korelacja Pearsona & 0.10 & 0.11 & 0.03 & 0.07 \\
\hline Sig (2-tailed) / istotność testu Sig (2-stronnego) & 0.12 & 0.09 & 0.65 & 0.26 \\
\hline
\end{tabular}

Abbrevaitions as in Table 3 / Skróty jak w tabeli 3.

* Correlation is significant at the 0.01 level (2-tailed) / Korelacja jest istotna na poziomie 0,01 (2-stronny). 
Table 3 shows spirometric indices among two groups. As noted, all the measured lung volumes (FVC, $\mathrm{FEV}_{1}, \mathrm{FEV}_{1} / \mathrm{FVC}, \mathrm{FEF}_{25-75 \%}$ ) have higher values in the unexposed group. However, only $\mathrm{FEF}_{25-75 \%}$ is significantly lower for the exposed workers compared with the unexposed workers $(\mathrm{p}=0.04)$.

Pearson's correlation analysis showed that $\mathrm{FEV}_{1} /$ FVC had a reverse relationship with age $(\mathrm{p}=0.000)$. Also $\mathrm{FEV}_{1} / \mathrm{FVC}$ and $\mathrm{FEF}_{25-75 \%}$ have such correlation with the length of employment ( $\mathrm{p}=0.000$ and 0.003 , respectively) (Table 4).

\section{DISCUSSION}

In our study, there were no significant differences in the major confounding variables of demographic, cigarette smoking and length of work between the exposed and unexposed subjects. The levels of inhalable cement dust observed in the current study are higher than the ones observed in developed countries such as the United States [15]. The inhalable dust exposure among the production workers in our present study is higher than American Conference of Governmental Industrial Hygienists Threshold Limit Values (ACGIH TLV), similar to the dust levels for cement production workers in Malaysia, Tanzania, the United Arab Emirates, Saudi Arabia and some other regions of Iran [1,3,6,16-20].

The prevalence of the respiratory symptoms in the 2 groups of our study was lower than the prevalence reported by similar studies $[3,6,7]$. Such a difference may be due to the questionnaires used in different studies or to the accuracy of completing the questionnaires. Most of the studies applied the American Thoracic Society's Questionnaire on Respiratory Symptoms with minor modifications. We used "The respiratory questionnaire of the national program of silicosis control" confirmed by the health ministry of Iran because of its reliability and validity in Persian language.

Respiratory symptoms were higher than in the control group, significantly more prevalent for cough and sputum ( $\mathrm{p}=0.049$ and 0.025 , respectively). These findings are similar to other reports $[7,11,16]$, and in contrast with some others [11,21]. Mwaiselage et al. found such association in a cross-sectional study among 120 exposed and 107 unexposed workers at a Tanzanian cement factory [8]. Siyoum et al. [22] designed a study to determine prevalence of respiratory symptoms and associated factors among Cement Factories Workers and compared it with the control group in Ethiopia. The odds of developing respiratory symptoms among cement factories workers were 7.6 times more than civil servants when adjusted for major confounders [22].

Kakooei et al. found no statistically significant association between cement dust exposure and respiratory symptoms in a smaller size sample [3]. Fell et al. studied 119 cement workers and 50 controls in Norway and also did not find an association between health outcomes (increased respiratory symptoms and decreased pulmonary function) and cement dust [9]. These different results could be explained by the difference of various races, exposure to dusts, duration of employment, genetic variations, accuracy of completing the questionnaire and use of personal protective equipments.

Kurniawidjaja conducted a study aimed to explore factors affecting the progression of silicosis other than exposure. He concluded that the genetic variation on TNF- $\alpha$ gene locus - 308 was a risk factor of silicosis in Indonesia cement factory [23]. Tungu et al. [24] assessed the prevalence of respiratory symptoms among the 134 exposed workers after 1 year of follow-up following an intervention campaign to improve use of personal protective equipment. They noticed that the prevalence of pulmonary symptoms significantly decreased in the intervention group compared to the previous year [24].

The lung function parameters $\mathrm{FVC}, \mathrm{FEV}_{1}$ and $\mathrm{FEV}_{1 \%}$ are lower in value among exposed workers compared with unexposed workers, but this reduction is not statistically significant. This is consistent with the finding of Rasmussen et al. [25] who did not find significant differences in lung function between cement factory workers $(\mathrm{N}=301)$ and other blue collar workers $(\mathrm{N}=649)$. Fell et al. [9] found that the mean pulmonary function indices were similar for cement mill workers and the control group (selected p from an ammonia producing industry). In contrast, Kakooei et al. [3] and Neghab et al. [5] and Al-Neaimi et al. [7] observed significantly reduced lung parameters among the exposed group maybe because of the difference in the length of employments (10 years in mean for our study compared to $14.8,18.8$ and 15.88 years due to the mentioned studies).

This assumption could be supported by the results of Olerue's [26] and Meo's et al. [27] study. Olerue conducted a case-control study and reported that the lung function parameters FVC and $\mathrm{FEV}_{1}$ were decreased with the duration of employment in cement industry [27]. Meo and his colleagues compared some spirometric indices in 50 non-smoking cement mill workers with 50 non-smoking un-exposed subjects. 
Based on the duration of exposure, cement mill workers were divided into 3 groups, less than 5, 5-10 and greater than 10 years. Their results showed a significant decrease in FVC and $\mathrm{FEV}_{1}$ with increased duration of occupational exposure to cement dust, clearly for more than 10 years of exposure [28]. Also in our study, $\mathrm{FEV}_{1} / \mathrm{FVC}$ and $\mathrm{FEF}_{25-75 \%}$ had a reverse relationship with the length of employment.

Neghab et al. [7] reported a significant reduction of lung volumes in the exposed group compared with the unexposed. The mean of inhalable dust concentration in the exposed group in their study was $53.4 \pm 42.6 \mathrm{mg} / \mathrm{m}^{3}$ vs. $23.13 \mathrm{mg} / \mathrm{m}^{3}$ in our study. Furthermore, the workers of the exposed group in our study use personal protective equipment and are under strict supervision. This factor was not mentioned in their article. Another possible reason for this difference is the selection protocol of the control group. Our control group was chosen from assumed un-exposed workers of the same industry because of the similarities in working conditions. The controls work in the same geographic area. We cannot be sure that there is no exposure among the control workers, while they carried out personal dust monitoring for respirable dusts and reported $0.00 \mathrm{mg} / \mathrm{m}^{3}$ dust exposure among the control group.

Also our results may have been influenced by some other limitations. Individuals susceptible to adverse respiratory effects from cement dust may have changed their task and therefore dropped out of the exposed group. Finally, lung function tests were performed during the working day that could cause a cross-shift effect of the cement dust in some workers. Yet, we believe that the validity of our findings is strengthened by the elimination of the effect of confounding variables, accessing to workers' pre-employment examinations to make assure they did not have previous respiratory diseases and the carefully chosen controls.

We found significant decrease in $\mathrm{FEF}_{25-75 \%}$ among workers in the exposure to cement dust in line with some other studies in agreement with similar studies with different sample sizes [3,7]. Although there are no recommendations regarding the utility of the percent predicted forced expiratory flow between 25\% and 75\% of vital capacity $\left(\mathrm{FEF}_{25-75 \%}\right)$ by the American Thoracic Society (ATS) [28], some studies shows that silica dust exposure can cause widespread fibrotic lesions in small airways, affecting mostly the walls of membranous and respiratory bronchioles and to a lesser degree alveolar ducts [29]. On the other side, this finding could be related to the other exposures other than cement dust in the exposed group. A more detailed respiratory hazard assessment in the cement factory is proposed as a future study.

\section{CONCLUSIONS}

In conclusion, the present study has demonstrated that the respiratory symptoms are associated with cement dust exposure. Our findings support the association between the duration of exposure to cement dust and the spirometry indices $\mathrm{FEV}_{1} / \mathrm{FVC}$ and $\mathrm{FEF}_{25-75 \%}$. Strict implementation of the Respiratory Protection Program is recommended in cement industries.

\section{ACKNOWLEDGMENTS}

The authors would like to thank the workers and management of the Portland cement factory for their cooperation.

\section{REFERENCES}

1. Zeleke ZK, Moen BE, Bråtveit M. Lung function reduction and chronic respiratory symptoms among workers in the cement industry: A follow up study. BMC Pulm Med. 2011;11:50, http://dx.doi.org/10.1186/1471-2466-11-50.

2. Occupational Safety and Health Administration. Worker safety series: Concrete manufacturing [cited 2014 Jun 25]. Available from: https://www.osha.gov/Publications/3221_Concrete.pdf.

3. Kakooei H, Gholami A, Ghasemkhani M, Hosseini M, Panahi D, Pouryaghoub G. Dust exposure and respiratory health effects in cement production. Acta Med Iran. 2012;50(2):122-6.

4. Meo SA. Health hazards of cement dust. Saudi Med J. 2004; 25(9):1153-9.

5. Al-Neaimi YI, Gomes J, Lloyd OL. Respiratory illnesses and ventilatory function among workers at a cement factory in a rapidly developing country. Occup Med. 2001;51:367-73, http://dx.doi.org/10.1093/ occmed/51.6.367.

6. Mirzaee R, Kebriaei A, Hashemi SR, Sadeghi M, Shahrakipour M. Effects of exposure to Portland cement dust on lung function in Portland cement factory workers in Khash, Iran. Iran J Environ Health Sci Eng. 2008;5(3):201-6.

7. Neghab M, Choobineh A. Work related respiratory symptoms and ventilatory disorders among employees of a cement industry in Shiraz, Iran. J Occup Health. 2007;49:273-8, http://dx.doi.org/10.1539/joh.49.273. 
8. Mwaiselage J, Bråtveit M, Moen BE, Mashalla Y. Respiratory symptoms and chronic obstructive pulmonary disease among cement factory workers. Scand J Work Environ Health. 2005;31(4):316-23, http://dx.doi.org/10.5271/ sjweh. 888 .

9. Fell AK, Thomassen TR, Kristensen P, Egeland T, Kongerud J. Respiratory symptoms and ventilatory function in workers exposed to Portland cement dust. J Occup Environ Med. 2003;45:1008-14, http://dx.doi.org/10.1097/01. jom.0000083036.56116.9d.

10. Antao VC. Lung diseases associated with silicates and other dusts. In: Rom WN, Markowitz SB, editors. Environmental and Occupational Medicine. 4th ed. Philadelphia (PA): Lippincott Williams and Wilkins; 2007, p. 525-42.

11. AbuDhaise BA, Rabi AZ, al Zwairy MA, el Hader AF, el Qaderi S. Pulmonary manifestations in cement workers in Jordan. Int J Occup Med Environ Health. 1997;10(4):417-28.

12. Ministry of Health and Medical Education. [Occupational and environmental health center. Guideline of silica exposure control at workplaces]. 2012. p. 26-30 [cited 2014 Aug 25]. Available from: http://www.ier. tums.ac.ir/files/site1/pages/silis_.pdf. Persian.

13. Miller MR, Hankinson J, Brusasco V, Burgos F, Casaburi R, Coates A, et al. Standardisation of spirometry. Eur Respir J. 2005 Aug;26(2):319-38.

14. American Conference of Governmental Industrial Hygiene. Threshold limits values for chemical substances and physical agents in the work environment and biological exposure indices. Cincinnati: Conference; 2009.

15. Abrons HL, Petersen MR, Sanderson WJ, Engelberg AL, Harber P. Respiratory symptoms, ventilatory function and environmental exposure in Portland cement workers. Br J Ind Med. 1988;45(6):368-75.

16. Ahmed HO, Abdullah AA. Dust exposure and respiratory symptoms among cement factory workers in the United Arab Emirates. Ind Health. 2012;50:214-22, http://dx.doi.org/10.2486/indhealth.MS1320.

17. Noor H, Yap CL, Zolkepli O, Faridah M. Effect of exposure to dust on lung function of cement factory workers. Med J Malaysia. 2000;55:51-7.

18. Ali BA, Ballal SG, Albar AA, et al. Postshift changes in pulmonary function in a cement factory in Eastern Saudi Arabia. Occup Med. 1998;48:519-22, http://dx.doi. org/10.1093/occmed/48.8.519.
19. Mwaiselage J, Bråtveit M, MoenB, Yost M. Variability in dust exposure in a cement factory in Tanzania. Ann Occup Hyg. 2005;49(6):511-9, http://dx.doi.org/10.1093/ annhyg/mei013.

20. Aminian O, Aslani M, Sadeghniiat Haghighi K. CrossShift Study of Acute Respiratory Effects in Cement Production Workers. Acta Med Iran. 2014;52(2):146-52.

21. Yang CY, Huang CC, Chiu HF, Chiu JF, Lan SJ, Ko YC. Effects of occupational dust exposure on respiratory health of Portland cement workers. J Toxicol Environ Health. 1996;49:581-8, http://dx.doi.org/10.1080/009841096160637.

22. Siyoum K, Alemu K, Kifle M. Respiratory symptoms and associated factors among cement factory workers and civil servants in North Shoa, Oromia Regional State, North West Ethiopia: Comparative cross sectional study. Occup Med Health Aff. 2014;2:182.

23. Kurniawidjaja LM. Silicosis and its progress influenced by genetic variation on TNF- $\alpha$ Locus-308, TNF- $\alpha$ and IL-10 cytokine on cement factory workers in Indonesia. Pak J Biol Sci. 2014;17(3):419-23, http://dx.doi. org/10.3923/pjbs.2014.419.423.

24. Tungu AM, Bråtveit M, Mamuya SH, Moen BE. Reduction in respiratory symptoms among cement workers: A follow-up study, health at inclusion. Occup Med (Lond). 2015;65(1):57-60.

25. Rasmussen FV, Borchsenius L, Holstein B, Solvsteen P. Lung function and long-term exposure to cement dust. Scand J Respir Dis. 1977;58(5):252-64.

26. Oleru UG. Pulmonary function and symptoms of Nigerian workers exposed to cement dust. Environ Res. 1984;33,379-85, http://dx.doi.org/10.1016/0013-9351(84) 90036-7.

27. Meo SA, Al-Drees AM, Al-Masri AA, Al-Rouq F, Azeem MA. Effect of duration of exposure to cement dust on respiratory function of non-smoking cement mill workers. Int J Environ Res Public Health. 2013;10(1): 390-8, http://dx.doi.org/10.3390/ijerph10010390.

28. Pellegrino R, Viegi G, Brusasco V, Crapo RO, Burgos F, Casaburi R, et al. Interpretative strategies for lung function tests. Eur Respir J. 2005 Nov;26(5):948-68.

29. Hnizdo E, Vallyathan V. Chronic obstructive pulmonary disease due to occupational exposure to silica dust: A review of epidemiological and pathological evidence. Occup Environ Med. 2003;60:237-43, http://dx.doi. org/10.1136/oem.60.4.237.

This work is available in Open Access model and licensed under a Creative Commons Attribution-NonCommercial 3.0 Unported License / Ten utwór jest dostępny w modelu open access na licencji Creative Commons Uznanie autorstwa - Użycie niekomercyjne 3.0 Unported - https://creativecommons.org/ licenses/by-nc/3.0/deed.en. 